\title{
Religionsfilosofi efter metafysik?
}

\author{
Professor dr.theol. Arne Grøn
}

\begin{abstract}
In his book Transformationen Gottes Vagn Andersen pursues a double strategy. First, he interprets Jürgen Habermas' post-metaphysical theory of communicative action as a last, secularized transformation of the idea of the absolute. More specifically, he argues that Habermas' theory combines two ways of reformulating this idea, a Hegelian and a Kierkegaardian one. This leaves us with a tension between a notion of history as a whole and a notion of human finitude. Second, Vagn Andersen addresses the question: given our modern condition as reflected in Habermas' theory, how is philosophy of religion possible? His answer draws upon a Kierkegaardian notion of the paradox leaving us with an unresolved tension between autonomy and heteronomy. This article discusses the approach and key issues in Vagn Andersen's book, such as the question of metaphysics, the concepts of transcendence and immanence, the relation between normativity, temporality, and dialogue, and the question of rationality and religion.
\end{abstract}

Key words: Philosophy of religion - metaphysics - post-metaphysics transcendence and immanence - normativity - temporality - subjectivity - communication - paradox - Jürgen Habermas - Vagn Andersen Søren Kierkegaard - G.W.F. Hegel

I forordet til sin disputats ${ }^{1}$ bemærker Vagn Andersen, at bogen ikke er skrevet blot for at meritere sig, men som forsøg på at orientere sig religionsfilosofisk i en modernitet, der anerkendes uden forbehold. I artiklen her vil jeg udtrykke min anerkendelse af dette projekt og måden, det er ført ud i bogen og livet på. Det vil jeg gøre ved at diskutere spørgsmål, som angår bogens anliggende. Der er en progression i spørgsmålene, som efterhånden skulle blive klar. Men først et kort rids af bogen.

1. Vagn Andersen, Transformationen Gottes. Abwandlungen des Begriffs des Unbedingten in der Moderne (Århus: Aarhus University Press 2008). Afhandlingen blev forsvaret for den teologiske doktorgrad 14. november 2008 på Det Teologiske Fakultet, Aarhus Universitet. - Alle sidehenvisninger er til Vagn Andersens bog. 


\section{På eftermetafysiske betingelser}

Med afhandlingen vil Vagn Andersen give sit svar på spørgsmålet om, hvorledes religionsfilosofi er mulig på moderne betingelser. Han sætter scenen op med følgende to greb. For det første præciseres spørgsmålet: Hvorledes er religionsfilosofi mulig på eftermetafysiske betingelser? For det andet gives svaret i en fortolkning og diskussion af Jürgen Habermas' teori om den kommunikative fornuft. Begrundelsen for det første skridt lyder: I den vestlige tænknings historie er religionen især to gange kommet under pres fra filosofien. Første gang var, da den i et mere positivt møde med filosofien transformerede sig til metafysik, hvorved der fulgte en næsten totusindårig epoke præget af metafysisk tænkning. Anden gang er situationen nu, hvor filosofien selv siger sig fri af metafysikken. Dette giver "die heutige religionsphilosophische Herausforderung" (14), som bogen tager op. Begrundelsen for det andet greb er, at Habermas' version af en eftermetafysisk tænkning ikke er reduktiv, men kendetegnet ved "et udblik til helheden og en normativ universalisme" (297).

Afhandlingen er opdelt i fire kapitler. Efter et kort indledningskapitel præsenteres i kapitel 2 "Nachmetaphysisches Denken" grundtrækkene i Habermas' modernitetsteori. Denne tager form af en teori om dialogisk rationalitet. Fornuften ligger ikke i det enkelte subjekt, men i det dialogiske spil mellem kommunikerende subjekter. Det afgørende træk ved modernitet er uddifferentieringen af fornuften i tre gyldighedsdimensioner: kognitiv sandhed, normativ rigtighed og subjektiv vederhæftighed. Det ligeværdige sammenspil mellem de tre dimensioner udgør fornuftens enhed. Problemet er at gøre rede for den ubetingethed, som er immanent i sproget. Habermas' tidlige konsensusteori for sandhed svinger mellem to forestillinger om, hvori denne ubetingethed ligger: først at kun en realt gennemført universel dialog kan indløse et sidste begreb om sandhed, og dernæst at enhver kommunikativ ytring er konsensuelt orienteret, hvormed forestillingen om en universel konsensus afsvækkes til at udgøre en regulativ idé. Der aftegner sig dermed en indre spænding i Habermas' kommunikationsteori. De krav på gyldighed, som vi kommunikerer med, er præget af et "Janusansigt": De gøres gældende her og nu, men er samtidig kendetegnet ved en transcendens af tid og rum. De er kontekstuelt bestemte, men peger samtidig i deres krav på gyldighed ud over deres kontekst.

Kapitel 3 forfølger denne dialektiske spænding under overskriften "Metaphysik des Schwebens". Der er ikke kun tale om en ubetingethed i form af en anticipation af totalitet, som griber ud over de enkelte øjeblikke, men også om en ubetingethed i form af en "egenfor- 
bindtlighed" i det enkelte historiske dialogøjeblik. Vagn Andersen vil $i$ kapitlet vise, at disse to begreber om ubetingethed forlænger to versioner af en "dennesidiggørelse" af det absolutte, "hvormed det 19. århundrede reagerede på den metafysiske gudstankes opløsning i Kants transcendentale dialektik, nemlig henholdsvis Hegels historiemetafysik og Kierkegaards "metafysiske" opladning af det endelige eksistensøjeblik" (295f). Hermed bliver Hegel og Kierkegaard så at sige de centrale bifigurer $\mathrm{i}$ afhandlingen. I den på én gang historiske og systematiske redegørelse for de to versioner af en dennesidiggørelse af det absolutte spiller desuden Heidegger og Gadamer vigtige roller. Mens den tidlige Heidegger forlænger linien fra Kierkegaard, løber de to linier - den hegelske og den kierkegaardske - sammen hos Gadamer: Med Hegel bedriver Gadamer en dennesidiggørelse af transcendens i form af en radikal historisk tænkning, og med Kierkegaard betoner han - via Heidegger - den definitive karakter af øjeblikket, som lader en "Rest von Transzendenz" skinne igennem (127f).

Vagn Andersens videre tese er nu, at de to tankelinier også samler sig hos Habermas. I første omgang søger han at vise, at Gadamer og Habermas hver især indfanger to måder, som et metafysisk begreb om det ubetingede forvandles på: i en transcendens udefra i form af en begivenhed, der overvælder os (Gadamer), og i en transcendens indefra i form af en bevægelse, vi selv sætter i værk (Habermas). Denne dobbeltbevægelse forstås som en "Metaphysik des Schwebens". De to bevægelser bringer hver på sin måde et moment af ubetingethed ved sproglig kommunikation til udtryk. Selv om de står i spænding til hinanden, udgør de kun tilsammen sprogets forbindende og forpligtende karakter.

I anden omgang søger Vagn Andersen derfor at vise, at spændingen mellem de to retninger, som en transformeret metafysik kan tage, findes hos Habermas selv: på den ene side at understrege anticipationen af helhed, på den anden side at betone endeligheden af det at eksistere historisk. Vagn Andersens fortolkning af Habermas skiller sig især ud ved at fremhæve, at også den anden traditionslinie fra Kierkegaard over Heidegger til Gadamer indgår i Habermas' tænkning. Tesen er her, at Habermas' begreb om diskursiv kommunikation betoner dennes endelige karakter. Det ubetingedes metafysiske vægt lægges over i den tidslige eksistens' dennesidighed. Det vises især ud fra Habermas' Wabrheit und Rechtfertigung fra 1999. Sandhed forstås her som det moment af vished, hvormed vi forlader os på "sandheden" af de overbevisninger, som styrer vores daglige håndtering af den os omgivende ydre verden (314). Til vores tidslige eksistens hører grundlæggende muligheden af at tage fejl. Vi er således situerede, 
at vi bevæger os mellem handlingsvished, problematisering og diskursiv retfærdiggørelse. Når en vished, som vi har levet med, bryder sammen, søger vi en ny tydning, som gør det muligt at leve videre i en fornyet dagligdags vished. Det er umuligt for os at eksistere som fallibilister. De to traditioner for at forstå det absolutte dennesidigt - en hegelsk og en kierkegaardsk - mødes hos Habermas i en gensidig begrænsning. Dermed bliver hans måde at forbinde de to tankelinier på mere spændingsfyldt og giver mere plads for subjektets autonomi end Gadamers.

Det er nu opgaven i kapitel 4 at drage de religionsfilosofiske konsekvenser af den eftermetafysiske tænkning, som især kapitel 3 har udfoldet. Dermed bliver Vagn Andersens dobbelte strategi tydelig. For det første søger han at vise, hvorledes det begreb om ubetingethed, som ligger i Habermas' kommunikative rationalitetsteori, kan ses som en sidste transformation af den metafysiske gudstanke. Det ligger i anti-naturalistiske "Residuen" i teorien for kommunikativ handlen (273). For det andet vil han selv besvare spørgsmålet om, i hvilken form teologi endnu måtte være mulig på baggrund af denne dens egen radikale sekularisering.

Kapitlet tager de to tankelinier fra Hegel og Kierkegaard op til fornyet overvejelse. Arven fra Hegel melder sig især på to punkter, som begge revideres hos Habermas. For det første søger han at forstå sin eftermetafysiske tænkning historisk som en foreløbig sidste station i en række af kontingente, men for os irreversible læreprocesser. Revisionen i forhold til Hegel består i, at den foreløbige karakter betones i et spørgsmål om eksistentiel "selvforvisselse" (317). For det andet er der også hos Habermas tale om en oversættelse i form af en sekularisering af en religiøs-metafysisk tradition. Revisionen består her $i$, at Habermas anerkender, at religionen kan rumme semantiske ressourcer, som er uopgivelige for at forstå og fastholde humaniteten, og som det endnu ikke er lykkedes at oversætte - og som måske heller ikke kan oversættes - til et filosofisk argumentativt sprog. Men det står åbent, hvorledes en religionsfilosofi så skal se ud.

Vagn Andersen forlænger her selv linien fra Kierkegaard. Det drejer sig nu ikke længere om en fortolkning af Habermas, men om Vagn Andersens eget bud på, i hvilken form religionsfilosofi er mulig i dag. Han begynder dog igen med Habermas, nemlig med bestemmelsen af den æstetisk-ekspressive subjektivitets sfære, der identificeres med spørgsmålet om subjektiv autenticitet.

Det fører Vagn Andersen frem til en mere eksegetisk tese om, at Kierkegaards "egentligste indsats består $\mathrm{i}$, at han har bedrevet teologi i et astetisk medium" (320). Gennem en bevidst selektiv, hermeneutisk rekonstruktion af Kierkegaard og med påberåbelse af K. Olesen 
Larsens prædikenpraksis søger Vagn Andersen at godtgøre sin videre systematiske tese, at den kristne arv kun kan leve videre i form af en æstetisk-ekspressiv sprogpraksis, som forstår sig som en stadig gentagen forkyndelse af den menneskelige eksistens' paradokse karakter (273). Hertil føjer sig afhandlingens "grundtese": "at kun en teologi, der formulerer sig på baggrund af sin egen radikale sekulariseringshistorie, i dag kan hævde sin egen forbindtlighed" (295). Hermed forbinder Vagn Andersen selv de to - tilsyneladende modstridende tankelinier fra Kierkegaard og Hegel: paradoks sprogpraksis og historisk bevidsthed. Kun en teologi, der forstår forkyndelse som paradoks sprogpraksis, er ifølge Vagn Andersen "kompatibel" med Habermas' teori om kommunikation som eftermetafysisk tænkning.

\section{Metafysik?}

Dette resumé yder ikke Vagn Andersens på én gang komplekse og pointerede afhandling retfærdighed, men skulle alligevel være tilstrækkeligt til at vise, at det er en afhandling, der virkelig fortjener en indgående diskussion. I det følgende går jeg uden omsvøb ind i en diskussion af nogle af de mange centrale spørgsmål, som bogen rejser. Jeg begynder med spørgsmålet om metafysik.

At tale om, at vi nu lever i en efter-metafysisk tidsalder, synes at kræve en klar opdeling mellem metafysik og ikke-metafysik. Men dermed er det let at overse, at der samtidig falder en særlig vægt tilbage på metafysikken. Den skal nemlig være stærk nok til at bære det afsæt, vi tager for at forstå de betingelser, vi nu lever under: at de er kendetegnet ved at være "efter metafysikken". "Efter-metafysik" hænger på metafysik. Hvorledes reflekterer en eftermetafysisk tænkning dette forhold til metafysikken?

At metafysikken binder i opgøret med den, er et motiv, vi kan finde hos Nietzsche, for den sags skyld også hos Kierkegaard og Hegel (måske også hos Luther). Nietzsche spørger, om Gud ikke er skrevet ind, ikke så meget i hjernen, som i grammatikken. Metafysik er som en skæbne, vi ikke kommer fri af. Til forskel herfra spørger Vagn Andersen efter rationaliteten i denne binding tilbage til metafysikken. Hvis vi skal forsøge at forstå, hvad det vil sige at tænke eftermetafysisk, kan der ikke være tale om, at metafysikken simpelt hen afskaffes, men at den forvandles. Det forsøger Vagn Andersen at indfange med udtrykket "Metaphysik des Schwebens". Vi er selv stillet i et svævende forhold til metafysikken: mellem at tage afsked med den og at opretholde forbindelsen til den. Men vil det sidste sige, at vi selv tænker metafysisk? I hvilken forstand er der tale om en "Metaphysik des 
Schwebens"? Det svar, som synes at aftegne sig med afhandlingen, er, at det er en metafysik, der bevæger sig mellem det absoluttes fravær og dets nærvær (255).

Men går Vagn Andersen langt nok? Når vi virkelig tilbage til metafysikken som spørgsmå? Før jeg går ind i en nærmere diskussion, vil jeg komme med et modspil i to trin. Det forste går netop på, hvorledes vi er stillet med metafysikken. Hvis selve det at tage afsked med metafysikken bringer metafysiske spørgsmål med sig, bliver det vanskeligere at tale afgjort om eftermetafysiske betingelser. Udtrykket "Metaphysik des Schwebens" kunne tages sådan, at vi skal være mindre sikre på, hvad metafysik og efter-metafysik betyder. Men det synes ikke at være, hvad Vagn Andersen har i sigte. I stedet spørger han dels efter den metafysiske rest i eftermetafysikken, dels vil han drage konsekvenserne af det at tænke på eftermetafysiske betingelser. Dermed afgiver metafysik og efter-metafysik epokale bestemmelser. Vi er $i$ en afgjort forstand efter metafysikken.

Men hvad vil det sige at tænke på eftermetafysiske betingelser? Ikke mindst i de seneste årtier har der ofte været en overraskende sikkerhed i måden at operere med globale størrelser som metafysik og eftermetafysik på. At pege på det svævende eller uafgjorte i forholdet mellem dem kunne modsat genåbne spørgsmålet om metafysik. Vi skal ikke tro, vi véd, hvad metafysik og efter-metafysik er, selv om det er, hvad vi gør - altså tror, vi ved, hvad de betyder.

I forlængelse heraf fører det andet trin direkte tilbage til metafysikken som spørgsmål. Det forhold, at metafysikken binder i opgøret med den, viser træk ved metafysikken selv - mere end ved opgøret. Hvis metafysik defineres ved det at hævde det absolutte, bærer den noget paradoksalt i sig. For hvorledes viser det absolutte sig? Det absolutte må vise sig i det forhold, at alle forsøg på at sætte noget som absolut lider skibbrud. Hvis vi kunne sætte noget som absolut, ville det ikke være det - ved selve denne akt. Men i så fald er det allerede metafysikken selv, der rummer en spænding, hvis ikke ligefrem en apori. Det forekommer mig at være den mest frugtbare vej at gå. Den indebærer, at skemaet med opdelingen i metafysik og efter-metafysik bliver brudt op, og gør samtidig forholdet mellem metafysik og religion mere interessant. Jeg vil her lade dette stå som et forslag. Hvad jeg har brug for til den følgende diskussion, er, at metafysik selv er et spørgsmål - i spørgsmålet om metafysik.

Hvad vil metafysik sige? Vagn Andersen opererer, så vidt jeg kan se, med følgende tre muligheder. For det første har metafysik med en tanke om transcendens at gøre. Hvis der er en "rest af transcendens", er der et forhold til metafysikken. For det andet er det afgørende for argumentationen i bogen (afspejlet i undertitlen Abwandlungen des 
Begriffs des Unbedingten in der Moderne), at metafysik er forsøg på at tænke det ubetingede, og at det er en opgave, vi selv står med. Den tredie mulighed er, at metafysik har med en tanke om totalitet at gøre. Således hedder det, at det at give afkald på en teori om totaliteten ligefrem definerer Habermas' eftermetafysiske tænkning (157). I dette afkald på kravet om totalitet ligger et modsatrettet krav, nemlig at den endelige karakter af vores eksistens er uomgængelig for os selv.

Hvorledes stiller dette os og metafysikken? På den ene side er der noget i den, som synes at skulle opgives: en forestilling om transcendens og et krav om totalitet. På den anden side der er noget uopgiveligt, nemlig tanken om det ubetingede, som skal reformuleres. Lad os først se på spørgsmålet om transcendens.

\section{Transcendens og immanens}

Begreberne immanens og transcendens har fået en selvfølgelighed over sig, som passer dårligt til de komplekse spørgsmål, de bærer på. At immanens og transcendens er problematiske begreber, kan ikke mindst en fortolkning af Hegels tænkning vise. Vagn Andersen hævder, at "Gud" hos Hegel betyder åndsstrukturen af totaliteten, som begriber sig selv (111), men diskuterer ikke for alvor, i hvilken forstand der her er tale om immanens, og hvad det betyder, at den hegelske filosofi bedriver "eine Verdiesseitigung der Transzendenz" (112). Han søger dog at nuancere immanens-transcendens skemaet, ikke mindst ved at inddrage Theunissens skelnen mellem transcendens udefra (som "indbrud" i menneskets verden) og indefra (som menneskets bevægelse ud over sig selv) (78-81). Men hvorledes forholder en "dennesidiggørelse af transcendens" sig til en sådan dobbelt transcendens udefra og indefra? I "dennesidiggørelse" synes transcendens at blive opløst i immanens, mens immanens omvendt synes at blive brudt op i den dobbelte transcendens.

Vagn Andersen skelner mellem to måder, som en dennesidiggørelse af transcendens er blevet bedrevet på. Den første er Hegels, nemlig at ophæve den metafysiske dualisme af immanens og transcendens, idet det absolutte begribes som "diesseitige Selbstexplikation des Ganzen" (128). Den anden er Kierkegaards, nemlig at det absolutte lægges ind i afgørelsen i øjeblikket. Men så vidt jeg kan se, er det bemærkelsesværdige, at der i begge tilfælde - $\mathrm{i}$ bevægelsen hen på totalitet (Hegel) og $\mathrm{i}$ bevægelsen hen på øjeblikket (Kierkegaard) - er tale om et overskud. Bevægelsen kan ikke indfange sig selv. Hos Hegel overskrides mennesket i sit forsøg på at forstå sig selv i den helhed, det indgår i. Hos Kierkegaard overskrides det i afgørelsen i øjeblikket, hvor det selv afgøres. 
Hvor kompliceret det er at operere med forholdet mellem immanens og transcendens, bliver tydeligere endnu hos Kierkegaard. At erindringens bagdør - med Efterskriftens udtryk - er lukket, lægger et uendeligt eftertryk på det dennesidige liv. Et menneske kan ikke redde sig selv ud af eksistensen og over i et evighedens perspektiv. Det ville jeg ikke uden videre formulere, som Vagn Andersen gør det, nemlig at Kierkegaard hermed lægger det absolutte ind i den menneskelige subjektivitets paradokse struktur (120). For hvorledes så gøre rede for vægten af det absolutte i øjeblikket? Pointen kommer bedre frem $i$ en anden formulering hos Vagn Andersen: Kun som forladt af en metafysisk Gud er et menneske under det absoluttes vægt og støder på den sande Gud. ${ }^{2}$ Men "dennesidiggørelse af transcendens" går her ikke så meget på at opløse transcendens i immanens, som at bryde tanken om immanens op indefra. Den bliver en dennesidiggørelse af transcendens, idet tanken om immanens ændrer sig med vægten af det absolutte.

Det er afgørende at fastholde problemet i det at bruge begreberne immanens og transcendens. ${ }^{3}$ Hvis vi vil hævde, at transcendens kan oversættes tilbage i dennesidighed (ved at forestillingen om en transcendent gud falder bort), får vi så immanens? ${ }^{24} \mathrm{Er}$ immanens noget, vi sådan kan få $\mathrm{i}$ hænderne? Kan begrebet om transcendens ikke netop indfange afgørende træk ved immanens, nemlig at immanens - selv om den bestemmes som den menneskelige verden - ikke er en position, vi kan etablere os selv i? Immanens er gådefuld. Den unddrager sig mennesket selv, som forsøger at begribe den. En sådan måde at bryde begrebsskemaet immanens og transcendens op på forekommer mig at være religionsfilosofisk mere attraktiv end de muligheder, som en mere traditionel tale om "dennesidiggørelse af transcendens" åbner for. Hvad vil det f.eks. sige at tale om en "rest af transcendens" (128)? Hvorledes bestemmer en sådan rest immanens, altså det, som det som rest af transcendens - optræder i? Hvis det absolutte skal gøres dennesidigt, hvorledes ændres så forståelsen af dennesidighed? Hvis "dennesidiggørelse" blot består i at føre transcendens tilbage til verden, som vi kender den, overser vi, at tanken om transcendens allerede forholder sig til verden. Den er motiveret af problemet med at forstå den verden, som transcendens er transcendens af. En "dennesidig-

2. "Um es pointiert zu sagen: nur als ein von dem metaphysischen Gott Verlassener stößt der Mensch auf den wahren Gott" (160).

3. Se min "Subjectivity and Transcendence: Problems and Perspectives", Subjectivity and Transcendence, red. A. Grøn, I. Damgaard og S. Overgaard (Tübingen: Mohr Siebeck 2007), 9-36.

4. Jf. min artikel "Jenseits? Nietzsches Religionskritik Revisited", Nietzsche-Studien 34 (2005), 375-408. 
gørelse af transcendens" er derfor kun mulig ved at gentænke transcendens, og det er igen kun muligt ved at åbne spørgsmålet om immanens. Transcendens bryder immanens op indefra.

Hvorledes stiller dette en metafysik? Vi kan hævde, at tanken om transcendens er bygget ind i meta-fysik. Men hvis vi tænker det metafysiske som det overnaturlige, bliver det til en størrelse, vi kan operere med på line med det naturlige. Det bliver så uforståeligt, hvorledes den metafysiske bevægelse samtidig er en bestemmelse af det, som den overskrider. Problemet ligger allerede i bestemmelsen af natur og det naturlige som immanens, som om naturen foreligger for os. Bestemmelsen af natur som natur kræver, at mennesket har en meta-fysisk natur.

At begreberne immanens og transcendens er problematiske at operere med, betyder ikke, at vi skal lade være. Tværtimod er de nødvendige for at indfange de spørgsmål, som viser sig, når vi forsøger at få greb om en menneskelig verden og menneskelig subjektivitet. Den verden, vi er i, foreligger ikke for os. Vi forholder os til den, $o g$ den kan overvælde os. Selv om vi er i den, kan vi også gøre erfaringer, hvor den taber sin fortrolighed. Immanens er ikke en position, vi kan etablere os i.

Lad mig kort sammenfatte. Totalitet synes at være et krav, som vi skal give afkald på, hvis vi vil tænke på eftermetafysiske betingelser. Det skal ikke blot forstås negativt, som det at opgive et krav, vi ikke længere kan opretholde, men også positivt, som det at gøre et andet krav gældende, nemlig at gøre alvor af menneskelig endelighed. Men som Habermas' tænkning viser, er spørgsmålet, om vi uden videre kan opgive kravet om totalitet. Vagn Andersen formulerer det således, at vi er stillet imellem nødvendigheden af et krav om totalitet og det at give afkald på det. Forestillingen om transcendens synes i første omgang også at måtte opgives eller rettere at oversættes til immanens, men ved nærmere eftersyn bliver det kritiske spørgsmål, hvad der kommer til at ligge i talen om en "dennesidiggørelse af transcendens". Spørgsmålet melder sig især med begrebet om det ubetingede. Jeg vil diskutere dette $\mathrm{i}$ to forbundne trin, først tidslighed, dernæst normativitet.

\section{Tidslighed}

Indebærer det ubetingede ikke en form for transcendens? Hvis det er tilfældet, hjælper det ikke at opgive forestillingen om transcendens for at fastholde tanken om det ubetingede. Hvorledes det ubetingede kan forstås "dennesidigt", bliver først og fremmest et spørgsmål om, hvorledes vi skal forstå det i forhold til tid og sprog. 
Jeg har allerede været inde på, hvorledes det absolutte hos Kierkegaard bliver et spørgsmål om tid, nemlig afgørelsen i øjeblikket. Men hvorledes kan tiden bære en sådan betydning, når tid er forandring og tilfælde? Det er kun muligt, hvis vores liv forstås som et liv, der afgøres i tid. I det at erfare tid ligger allerede en vægt eller byrde, nemlig det at udholde sig selv i tid. Det er den vægt, der træder frem i angst og kedsomhed. I tiden, der bliver nøgen og står ud, kan det ubetingede melde sig. Vægten i tid (af det at leve i tid og dermed at skulle være sig selv i tid) kan lade vægten af det absolutte (afgørelsen i tid) træde frem. Øjeblikket skal dermed ikke forstås som enkeltstående, men som spørgsmål om det liv, der afgøres i øjeblikket - hvorved afgørelsen bliver et spørgsmål om at bære afgørelsen i tid.

Men betyder det, at det absolutte lægges ind i tid eller går op i tid? Vagn Andersen vil vise, at "das Absolute sich - jedenfalls beim späteren Habermas - in ein Moment unseres zeitlichen Existierens verwandelt hat, und daß es insofern in das Diesseits verlegt ist" (170). Det er en "Verdiesseitigung des Unbedingten" (ibid.). Men hvis det netop ikke skal betyde, at det ubetingede opløser sig i tidens betingelser, må bevægelsen 'ind i' tid være en dobbeltbevægelse, idet den kun er afgørelse i tid ved at være afgørelse af tid. Denne afgørelse angår den tid, som skal komme, og den kommende tid foreligger ikke. Hvis vi vil operere med en tidens immanens, bliver det vanskeligt at forstå de afgørende forskelle i tid, som vi har vores liv i. Så lidt som tid og transcendens falder ved siden af hinanden i to verdener, så lidt opløser transcendens sig i tid. Der er nærmere tale om en transcendens i tid af tid. 5

Vagn Andersen overvejer selv, om Theunissens tanke om en dobbelt transcendens (som indbrud i menneskets verden og som menneskers bevægelse ud over sig selv) kan formuleres således, at de to måder at forstå det ubetingede ved dialogen på kan forbindes: på den ene side det ubetingede i form af en sandhed, der overgår og overtræffer os (Gadamer), på den anden side det ubetingede i form af krav på gyldighed af vore egne ytringer (Habermas). Men ligger pointen ikke allerede i måden, som det ubetingede viser sig på i de to versioner? I det sidste viser det sig i det, at der er mere i vore krav på gyldighed, end vi selv lægger i dem: de afgøres ikke af os selv, men ud over os. ${ }^{6}$ Og i det første i det, at det er en sandhed, vi skal finde os selv i.

5. Se min "Zeit und Transzendenz", Der Sinn der Zeit, red. E. Angehrn et al. (Weilerswirst: Velbrück Wissenschaft 2002), 40-52.

6. Der er ikke kun tale om en "Transzendenz von Innen" (Habermas) i form af gyldighedskrav, der overstiger rum og tid, her og nu. Intentionen om almengyldighed bliver afgjort ud over den, som har denne intention. 
Men spørgsmålet bliver også, hvorledes vi skal forstå dialogens tidslige karakter. På den ene side fører vi selv dialogen mellem os, på den anden side finder den sted mellem os. Den sandhed, vi måske når frem til i dialogen, er ikke blot en sandhed, vi bliver enige om, men en sandhed, der viser sig for os. Den bliver ikke blot konstrueret, men finder sted i dialogen - hvis den gør det. For at dét ikke er givet, hører også til dialogens tidslighed. Sandhed er ikke uden videre det, som kommer ud af dialogens bevægelse, hverken i form af en fælles overenskomst (Habermas) eller i form af magten til at sætte sig igennem (Gadamer).

Hvis vi forsøger at føre det ubetingede ind i tid (afgørelsens tid) og sprog (dets forbindende kraft), viser det ubetingede sig i det, vi læser det ind i. Det viser sig først og fremmest som et spørgsmål om karakteren af dette: tid og sprog. Det får selv karakter af et åbent spørgsmål: Er det afgørelsens (sandhedens) tid og forpligtelsens (sandhedens) sprog? Det er ikke givet, at det ubetingede viser sig således, at det sætter sig igennem i tid og i sprog.

Men hvorledes viser det ubetingede sig så? Viser det sig ikke allerede deri, at vi ikke indfanger det? Hvis vi kunne, ville det ikke være det ubetingede. Men det ubetingede viser sig ikke kun som et åbent spørgsmål om det ubetingede. Hvis det ubetingede skal forstås som det forpligtende, melder det sig så ikke i form af en etisk appel, som ikke er nogens appel, hvor meget vi end kan give den stemme? Og hænger det ikke sammen med den faktiske karakter af det liv, vi allerede lever?

Vagn Andersen fremhæver, at Habermas ikke kun lægger det ubetingede ind i en formal struktur ved den dialogiske fornuft, men også forbinder det med den alvor, der ligger i, at vi allerede er situerede. Alligevel er det, som om det ubetingede mere læses ind i dette at overskride den faktiske eksistens med dens øjebliksbestemte krav på gyldighed. Men hvis det ubetingede skal betyde det forpligtende, kræver det os således, at vi selv skal svare for, hvad vi får det til at sige. Det betyder, at den forpligtende karakter ikke kan forklares ud fra dialogens bevægelse mellem os. Tværtimod forudsætter denne, at vi hver især går ind i dialogen med alvor. Der er en vægt i det selv at være tidslig, som ikke går op i dialogens tidslighed i bevægelsen mellem os. Det er den vægt, der falder på os, idet vi hver er stillet med os selv og skal svare for os selv - med vores faktiske eksistens. At det etiske "singulariserer" (som både Kierkegaard og Levinas - og Løgstrup betoner), er ikke et resultat af dialogen, men bestemmer allerede dialogens karakter. 


\section{Normativitet}

I forsøget på at finde et svar på spørgsmålet om, hvad det vil sige at tænke det absolutte som dennesidigt, er vi med Vagn Andersen nået til det ubetingede som det forpligtende. Men hvorledes skal vi gøre rede for det forpligtende eller forbindtlige (altså det, som forpligtende forbinder os)?

Umiddelbart kan bevægelsen tilbage til det dennesidige forstås således, at det forpligtende selv føres tilbage til krav, vi kan gøre gældende over for hinanden. Hvis det ubetingede læses ind i sproget, kommer den bindende kraft i sproget til at ligge $i$, at jeg appellerer til den anden og omvendt. Dermed føres forpligtelse og forbindtlighed tilbage til dette, at vi hver især appellerer til hinandens stillingtagen og måske gør krav på hinandens tilslutning. Men hvad skulle binde os heri? Det at den anden appellerer til, at jeg tager stilling på en bestemt måde, kan ikke binde min stillingtagen. Hvis jeg følger den andens appel, gør jeg selv noget - siger ja og tilslutter mig. Vi kan så forsøge med Habermas at knytte den (for)bindende kraft til en fornuft i dialogens bevægelse. Men igen er spørgsmålet, hvad vi får en sådan fornuft til at sige. Enten reduceres det forpligtende til det, at vi faktisk gør krav gældende over for hinanden, eller det tager form af spørgsmål, vi selv skal svare på med vores stillingtagen. I det første tilfælde bliver problemet at skelne mellem (almen)gyldighed og krav på gyldighed. Det hjælper ikke at tale om en intention om universel gyldighed. For forpligtelse kan ikke reduceres til intention om forpligtelse.

Det spørgsmål, som aftegner sig, er, om forpligtelse er et spørgsmål om overenskomst. Kan vi beslutte os til, hvad der er forpligtende for os? I en vis forstand gør vi det jo - det, som gælder mellem os, er det, som vi lader gælde mellem os. Men det gælder ikke uden videre. Der følger ofte spørgsmål med, om det nu også er rigtigt - det vi lader gælder som rigtigt (hvis det overhovedet er klart, hvad "vi" lader gælder mellem os). Følgende passage er i denne sammenhæng central:

"Es gibt nach Habermas keine - der objektiven Außenwelt analoge - vorgegebene Welt von moralischen "Tatsachen”, mit denen wir zurechtkommen müssen, und an denen wir scheitern können. Die soziale Welt der normativen Verpflichtung erzeugen wir selbst, indem wir durch diskursive Rechtfertigung intersubjektiv einleuchtende Verpflichtungen eingehen und damit Normen stiften. Insofern ist die moralische Welt unsere eigene Konstruktion" (148).

Dette rummer en række spørgsmål, som fortjener en udførlig diskussion, men som jeg her kun kan opregne som skridt på vejen. For det første, hvis det er som beskrevet, hvorledes gør vi så rede for, at det, vi enes om, er, hvad vi hver især finder indlysende? Er dette, at vi 
hver især finder noget indlysende, også en social konstruktion? For det andet, bliver forpligtelse vores egen konstruktion? Er forpligtelse noget, vi giver os selv? Habermas' svar er, at vi ikke kun er autorer til forpligtelse som selvlovgivning, men også adressater. Men det forskyder kun problemet til at gøre rede for, hvad det vil sige, at vi er adressater for forpligtelsen. Habermas' svar er, at det ligger i det almengyldige, der oversættes til det for alle acceptable. Men hvis forpligtelse og forbindtlighed er, hvad vi enes om, forsvinder forklaringskraften. Habermas opererer her igen med forestillingen om, at vi i en uendelig diskurs bliver enige. Men for det første tænkes historien hermed totaliserende, ganske vist $\mathrm{i}$ et idealiserende greb: Kredsen af deltagere i samtalen udvides "innerhalb der Geschichte selbst" (151). Hvad skal det sige? Er vi således "inden for" historien? Og reduceres normativitet ikke til et spørgsmål om faktisk enighed? For det andet sætter Habermas ud af kraft, hvad Vagn Andersen fremhæver hos ham: tidslighed. For vi er ikke samtidige i det at afgøre, hvad der er normativt forpligtende. Vi forholder os til fortidig uret og til mulig fremtidig uret. Hvad skulle det så betyde, at den moralske verden er "vores" egen konstruktion? Hvorledes kan vi gøre rede for den forudsætning, Habermas gør, nemlig at der også i moralske spørgsmål kun er ét for alle - gyldigt svar?

En fælles konstruktion af forpligtelse forudsætter ikke kun, at vi kommer overens om det, vi hver især finder indlysende, men også at den enkeltes indforståelse er utvungen. Hvorledes afgøres det? I menneskelig kommunikation spiller muligheder for manipulation med på måder, der ikke er kontrollerbare. Offentlighed har en tendens til at blive andet end rum for fri diskussion af fælles anliggender. Betyder det ikke, at vi er nødt til at operere med både sandhed og rigtighed som noget, der udestår, og som vi skal opdage, idet de ikke går op i alle vore afgørelser? Er der ikke stumme partnere også i diskurser om moralsk rigtighed? ${ }^{7} \mathrm{Vi}$ kan sige, at alle skal være med, men ligger der ikke forpligtelsen på den, der fører ordet: at være opmærksom på dem, som ikke er med - måske i fortiden eller fremtiden? Selv om menneskelige historier er kendetegnet ved, at enhver har sin egen stemme, er det ikke enhver, der kan komme til orde i det, som tager sig ud som en fælles historie. Ændrer forpligtelsen eller forbindtlig-

7. Med naturen "gibt es dagegen keine Kommunikation im strikten Sinne". I teoretiske diskurser spiller naturen med "als dritter stummer Partner", "während es in praktischen Diskursen keine stummen Drittpartner gibt. In der Beantwortung normativer Fragen des gegenseitigen Verhaltens sind wir (auch unter potentieller Inklusion aller Mitglieder der ganzen Menschheitsgeschichte) sozusagen "unter uns" als sprachfähige Wesen. Hier hat jeder seine Stimme und kann selbst und in eigener Sache zu Worte kommen“ (151). 
heden ikke hermed karakter? Og er det ikke, hvad et religiøst sprog også kan artikulere?

\section{Rationalitet og religion}

Selv om Vagn Andersens afhandling drejer sig om, hvad religionsfilosofi er, virker det, som om vi først får med religionsfilosofien at gøre i slutkapitlet "Folgen für die Religionsphilosophie". Jeg kan kun se det sådan, at religionsfilosofien har været med hele vejen - i diskussionen af transcendens, immanens, det ubetingede. Det må Vagn Andersen også hævde, når han indsnævrer den religionsfilosofiske udfordring til et spørgsmål om metafysikkens mulighed. Men kan det, vi forstår ved religion, indfanges af dette spørgsmål? Hvis vi forstår metafysik som rationaliseret religion, står der også her et spørgsmål om oversættelse åben. Forbliver der ikke også i metafysikken et forhold til religion, som ikke går op i metafysik? Er det ikke, hvad der gør forholdet filosofisk udfordrende? Progressionen i de temaer, jeg har taget op i det foregående, har også dette sigte at lede tilbage til spørgsmålet om religion og rationalitet.

Hvorledes taler religion om det ubetingede? Kan det hellige som det, der skal binde et menneske i det, som det gør, oversættes til det ubetingede som det forpligtende? Hvor langt kan en sådan oversættelse gå? Det svar, vi kan læse ud af Vagn Andersens forlængelse af den kierkegaardske linie, lyder således. En religiøs sprogpraksis "hält semantische Potentiale am Leben, die noch einer philosophischen Übersetzung harren, und sie weckt - obwohl sie sehr wohl mit dem Programm einer ständigen philosophischen Übersetzung vertragen kann - berechtigte Zweifel, ob dieses Programm jemals zu einem definitiven Ende geführt werden kann" (256, jf. 190). Men spørgsmålet er, om dette semantiske potentiale ikke netop angår forståelsen af det ubetingede som det forpligtende. Så vidt jeg kan se, bevæger Vagn Andersen sig i den modsatte retning og lader i sin anvendelse af Kierkegaard spørgsmålet om det etiske og det religiøse gå op i det æstetisk-ekspressive (understøttet af identifikationen af subjektiv vederhæftighed som æstetisk-ekspressiv). Hvis religion går op i æstetiskekspressiv sprogpraksis, i hvilken forstand kan der så være tale om en oversattelse af religion?

Hvis det religiøse (hellige) på forhånd er oversat til sproglig forbindtlighed, kan vi så gøre rede for de spørgsmål om forpligtelse, som vi er mennesker igennem? Rummer det religiøse ikke her et stærkere semantisk potentiale, idet det peger på det etiske som forpligtende i en betydning, der ikke udtømmes ved, at vi forpligter os? Jeg vil for- 
mulere det sådan, at det gælder om at bringe spørgsmålet om det religiøse tilbage som et spørgsmål om oversættelse. I stedet for blot at gå fra det religiøse til en oversættelse af det må vi tage bevægelsen tilbage til det, der skal oversættes, og se på det én gang til.

Problemet ligger i forståelsen af karakteren af forpligtelse. Umiddelbart er det slående, at vi ikke vil kunne forpligtes, hvis vi ikke forpligter os selv. Forpligtelse har en autonom, selvlovgivende karakter. Vi kan ikke forpligtes således, at en anden eller andre forpligter os. For det at forpligtes er selv at blive det, og heri ligger: selv at stå inde for det. Men at vi forpligtes er ikke det samme som, at vi faktisk forpligter os selv. Selv om det at blive forpligtet kræver, at vi forpligter os selv (andre kan ikke forpligte os for os), falder det ikke sammen. Forpligtelsen forsvinder ikke ved, at vi ikke lader os forpligte. For så vidt kan vi være forpligtede uden at forpligte os selv. Vi kan svigte. Og det er afgørende for at forstå normativitet.

Men har det semantiske potentiale, som religion rummer, ikke med dette at gøre, at vi ikke kan give os selv den forpligtelse, som vi skal lade os bestemme af? Vi kan bestemme os selv i forhold til en appel, men ikke selv konstruere denne. Dette spørgsmål - om vi kan "konstruere" forpligtelse forstået som dette selv at være forpligtet har med et andet spørgsmål at gøre: Hvor langt kan vi gøre rede for det, som forpligter os? Forpligter det os først, når vi kan gøre rede for det?

Dette bringer spørgsmålet om religionsfilosofi i centrum. Vagn Andersen bemærker allerede i sin indledning, at religionsfilosofi forudsætter, at filosofi har frigjort sig fra religion og etableret sig "als autonomer Gerichtshof eigenständigen humanen Vernunftgebrauchs" (13). Filosofi kan begrunde og legitimere "durch freie und unabhängige Vernunfteinsicht” (ibid.). Men så vidt jeg kan se, ligger filosofiens menneskelige autonomi nærmere i det at spørge efter, hvor langt vi kan begrunde og legitimere vores grundoverbevisninger - og hvad det vil sige at gøre det. Dette skal ikke forstås som en svækkelse af rationalitet, snarere tværtimod. Religionsfilosofi drejer sig om forholdet mellem rationalitet og religion. Den er ikke en overførsel af rationalitet på religion, men omvendt et spørgsmål om at skærpe og udfordre vores forståelse af rationalitet.

\section{Paradoks og praksis}

Som vi har set, tager Vagn Andersens svar på spørgsmålet om, hvorledes vi skal forstå religionsfilosofi på eftermetafysiske betingelser, form af en fortolkning af Kierkegaard. Dermed er også sagt, at denne ikke 
så meget skal bedømmes på, hvorvidt den nu også kan gøre rede for, hvad Kierkegaard skriver. Alligevel er der grund til at nævne nogle punkter, hvor jeg mener den går fejl af de kierkegaardske tekster, og hvor de systematiske perspektiver samtidig spiller afgørende med. Jeg nævner fire punkter, for så at slutte af med det, som kan kaldes Vagn Andersens tese.

Først bestemmelsen af mennesket som en syntese. Vagn Andersen skriver, at syntesen af frihed og nødvendighed allerede er fortvivlelse (116f, 120). Hvis det var tilfældet, ville det være umuligt at skelne mellem det, at et menneske er bestemt som en syntese, og det, at syntesen mislykkes. Oven i købet siger Vagn Andersen med Walter Schulz, at synd er et ontologisk strukturmoment i den menneskelige eksistens (231). Hvis det var tilfældet, ville den afgørende skelnen i Begrebet Angest falde bort: mellem, hvad et menneske som kontekstuelt bestemt væsen er blevet gjort til (syndighed), og hvad det selv gør (synd).

Dernæst historie. Vagn Andersen hævder, at mens der hos den tidlige Kierkegaard kan findes spor af en historiefilosofi af et vist hegelsk tilsnit, "ist der offizielle, inhaltliche Diskurs des späteren Kierkegaard von jedem geschichtlichen Bewußtsein merkwürdig unberührt" (243). Det sker bl.a. med henvisning til, at det overalt drejer sig om en lidenskabens "primitivitet". Jeg vil snarere hævde det modsatte: det drejer sig om forholdet mellem lidenskabens primitivitet og historie. Begrebet Angest kredser om, hvorledes et menneske selv får historie inden for en slægtens historie, som det selv allerede er begyndt i. Betoningen af lidenskabens primitivitet går på dette selv at begynde inden for en historie, der allerede er begyndt. Denne dobbelte betoning af primitivitet og historicitet præger forfatterskabet efter Begrebet Angest.

For det tredie, når Vagn Andersen samler Kierkegaards arv i afgørelsen i øjeblikket (158ff), er spørgsmålet, om han får gjort tilstrækkeligt rede for øjeblikkets tidslighed. For i øjeblikket står et menneskes eksistens på spil. I øjeblikket rummes for så vidt et blik frem og tilbage på helheden af det liv, som bliver afgjort i øjeblikket.

For det fjerde subjektivitet. Vagn Andersen bestemmer den eksistentielle fakticitet som en subjekt-objekt identitet (114). Er den det? Mit spørgsmål går ikke kun på fortolkningen af Kierkegaard, men også på selve begrebet om en subjekt-objekt tænkning (og den skematiske modsætning til en intersubjektivitetsteori). Hvis begyndelsen af Sygdommen til Døden, som Vagn Andersen efterfølgende citerer in extenso, fortolkes ud fra en subjekt-objekt model, bliver det vanskeligt at forstå, hvad der ligger i dette, at et menneske er et forhold, der forholder sig til sig selv. I stedet vil jeg forsøge at fortolke Kierkegaard 
således, at et menneske forholder sig til sig selv i det at forholde sig til den anden og til verden. Det vil sige: at tænke subjektivitet som forbindelsen mellem subjektivitet, forholdet til den anden og verden. At et menneske har sig selv i forhold til andre og til verden, vil jeg se som "dramaet" i både angst- og fortvivlelsesanalysen: at et menneske kan tabe - og vinde - sig selv i forhold til andre og verden.

Endelig Vagn Andersens tese: "nur in der Weise, wie Kierkegaard darüber redet, existiert überhaupt das, wovon er redet. Das 'Paradox' Kierkegaards ist insofern kein außerhalb seines Textes bestehender Sachverhalt, sondern ein erst durch den Text selbst exekutierter Sachverhalt" (225). Men at paradokset virker i, hvorledes vi kan tale om det, betyder ikke, at det kun er i måden, vi taler om det på. Hvis paradokset først er noget, som "eksekuteres" gennem teksten, bliver det vanskeligt at forstå, at teksten kan få den vægt, som den her skal bære. Paradokset er nærmere kendetegnet ved, at det netop ikke kan "eksekuteres" eller praktiseres, og at det netop derved bestemmer en praksis. Paradokset opløser sig ikke i en sprogpraksis, for denne er selv kendetegnet ved ikke at kunne opløse paradokset. Når paradoksien i den kierkegaardske diskurs består i, "daß gerade das Gericht die Vergebung und gerade die Vergebung das Gericht ist" (235), er det netop ikke noget, teksten ' $\mathrm{g} ø \mathrm{r}$ '. Kierkegaards tale făr - siger Vagn Andersen - den paradokse form, at den i ét og samme øjeblik kan være dom for den ene og redning for den anden. "Insofern vollzieht sich in dieser Rede auch Gnade" (235). Men betyder det, at nåden kun er i måden, der her tales om den på?

\section{At tænke epokalt}

Vagn Andersens afhandling gør ikke mindst indtryk ved at insistere på kravet om, at vi skal gøre os de betingelser klar, som vi nu tænker under. Vi kan ikke leve et liv på modernitetens betingelser og så tillade os ikke at gøre alvor af det i måden, vi tænker på. Det er et motiv, Vagn Andersen genfinder hos Habermas. Det drejer sig om på én gang at forstå os selv historisk ud fra de erfaringer, hvormed vi er blevet dem, vi er, og at forstå, hvad der $i$ dag er forpligtende. At værdsætte traditionen er at tage det moderne på sig, som den har ført frem til.

At filosofi er forsøg på (med Hegels ord) at fatte sin tid i tanker, bliver let til et forsøg på at være på højde med tiden, og det resulterer ikke kun i mainstream, men også $\mathrm{i}$, at man konstant løber efter tiden. Vagn Andersens projekt er modsat at give sig tid til at tænke spørgsmålet efter, hvilken tænkning der er mulig på modernitetens vilkår. 
Selv om jeg for så vidt deler dette anliggende, bliver jeg nødt til at slutte af med at udtrykke en vis uro ved talen om det, der gælder "nu". Det forekommer mig, at der kan komme noget skematisk, undertiden kategorisk, i formler som f.eks.: "unter heutigen Bedingungen nachmetaphysischen Denkens" (221)" og "unter den Prämissen einer nachmetaphysischen Theorie der kommunikativen Vernunft, die sich von der Subjektphilosophie losgesagt hat ...” (195). Så vidt jeg kan se, bliver spørgsmål her afgjort, som mere skulle stilles på ny. Jeg kan formulere det mere principielt: At filosofi er at fatte tiden i tanker må også betyde at spørge til de betingelser, vi nu tænker under, både som et spørgsmål om, hvad de betyder, og som et spørgsmål om grænserne for vores epokale forstålse (for nu at formulere det på den måde). Selv om vi vanskeligt selv kan svare på spørgsmålet, må vi alligevel stille det: Hvad er det, vi netop nu ikke ser? Min fornemmelse er, at det at gøre det til en pointe at tænke epokalt er et træk ved tiden nu, som bærer på sine egne problemer. Det viser sig i en ofte skematisk omgang med historien, også når vi gør det til en pointe at tænke os selv historisk. For så vidt er vi hermed tilbage i spørgsmålet om metafysikken - som de spørgsmål, den selv rummer. Også før i tiden har mennesker ikke blot erfaret, som de har fortolket.

Det siger sig selv, at jeg heller ikke med denne diskussion har ydet Vagn Andersens afhandling retfærdighed. Det er sjældent, at en afhandling så konsekvent fører overvejelser over grundlaget for religionsfilosofien igennem. Vagn Andersens afhandling er frugten af mange års intenst arbejde. Det er en stolt tradition for religionsfilosofisk forskning ved Det Teologiske Fakultet ved Aarhus Universitet, som hermed på fornem vis videreføres. 